\title{
Mapping the Global Dust Storm Records: Review of Dust Data Sources in Supporting Modeling/Climate Study
}

\author{
Julian X. L. Wang ${ }^{1}$ \\ Published online: 23 June 2015 \\ (C) Springer International Publishing AG (outside the USA) 2015
}

\begin{abstract}
Dust storms, as extreme environmental events, are one of the Earth's major natural hazards. Their impact on socio-economics can range from local urban to (trans-) continental and from minutes to decades, such as the dust bowl of the 1930s in the United States. Research on dust storms can be traced back for several decades as a meteorological extension. Latest technology developments have enabled comprehensive studies on dust storms, including sampling improvement, analytic studies, and numerical modeling. However, inhomogeneity of the data has hampered and sometimes even misguided research on comprehensive understanding of dust storms and exploring their feedbacks with climate. This review will focus on currently available observations of dust activities, which include routine meteorological records, in situ air chemistry observations, and satellite remote sensing. The aim is to show data sources and the status of their usage in a common framework for global dust regions. Emphasis is placed on data continuity and the spatial and temporal coverage of dust storms, since it is anticipated that this brief summary of dust data will benefit modeling and climate studies. Therefore, it must be noted that field campaign data are outside of the scope of the current review, although they play an important role in research and understanding.
\end{abstract}

Keywords Dust weather · Dust storm monitoring and definition · Dust aerosol observation · Dust data quality . Global deserts

This article is part of the Topical Collection on Air Pollution

Julian X. L. Wang

Julian.Wang@noaa.gov

1 NOAA, Air Resources Laboratory, College Park, MD, USA

\section{Introduction}

A dust storm or sand storm is a meteorological phenomenon common in arid and semi-arid regions. The term sand storm is used mostly in the context of desert sandstorms, especially in the Sahara Desert, or places where sand is a more prevalent soil type. The term dust storm is more likely to be used when finer particles are blown long distances, especially when it affects urban areas. In context of this review, both terms are referred as dust storm [1].

Dust storms are a major natural hazard in many parts of the world. As a major source of particulate matter, they bring dust particles into the air, which can reduce visibility, affect the breathing of human and animals, cause the reduction of agriculture produce, and further affect socioeconomic orders. For instance, serious dust storm hazards during the 1930s created one of the most severe environmental catastrophes in US history and led to the popular characterization of much of the southern Great Plains as the "Dust Bowl" [2]. Recent seasonal dust storms in China have seriously affected the capital city Beijing [3], resulting in bad air quality, increased traffic accidents, and more respiratory diseases $[4 \bullet \cdot]$. Therefore, studies on dust storm activities will greatly benefit human society. Unfortunately, systematic studies on the characteristics and mechanisms of dust storms have yet to be performed in many parts of the world [5]. The main obstacle that hampers understanding the dust climatology and developing numerical prediction techniques $[6 \bullet \cdot$ is the lack of consistent dust storm records.

Since there is no specifically designed observing network for dust storms, recent research and developmental efforts have focused on construction of systematic records for historical dust storms based on available observations of multiple networks $[5,7,8]$. These observations include regular meteorological observations, air quality observations, stationary optical observations, and satellite dataset [9••]. The approaches in 
reconstruction of dust storm records are usually based on certain physical connections between dust and the observed physical factors $[10 \bullet \cdot$, such as wind speed and direction. The reconstructed dust storm records would contain specific limitations [10••] for each observation method. The availability and quality of these datasets vary among different regions, which results in not all types of dust records available and useful in a region. Although reconstructed dust storm records could reveal certain characteristics of dust activities and might benefit applications such as agriculture, caution must be taken while analyzing and comparing these records. In research, there is a huge need to compare these reconstruction methods and check the availability and quality of reconstructed records.

The purpose of this work is to review the principal types of dust storm records and available data sources over the major dust storm-affected regions including Sahara desert, Gobi desert, Arabian Desert, Australia deserts, North American desert, and South American deserts. The major issues affecting potential applications of the observational records are also discussed. In addition, the characteristics of dust storms over each desert region are also composed and analyzed. It is anticipated that this review could serve as a reference for the use of dust storm datasets and provide a summary of the characteristics of dust storms over major desert regions.

\section{Major Data Sources Used as Dust Records}

\section{Meteorological Records for Dust Weather Conditions}

Regular meteorological records include information that can be used to characterize dust storm activities. These include the descriptions for weather conditions, wind speed, visibility, and air pressure. Among the observed physical variables in a standard meteorological record as described by the World Meteorological Organization (WMO), two types of observations, dust weather codes and visibility, are used as direct dust weather indicators [11]. In this section, we mainly focus on methods that can directly result in datasets for dust storm activities. The dust weather codes included in the regular meteorology record show directly the strength of dust storm conditions. Table 1 shows all the codes and their corresponding descriptions of dust weather conditions.

We noticed that these codes could describe dust weather from weak to strong in a continuous sequence. Therefore, they can provide a wide variety of information on historical dust storms. Recent studies use this information to reconstruct dust storm climatology over different regions of the world. By determining whether a storm code is recorded on a single day, daily dust storm/dust weather frequencies can be constructed to study dust climatology $[10 \bullet, 12,13]$. Further analysis of computed dust climatology with other meteorological parameters shows that these meteorological codes can represent dust storm activities on a climate scale. More comprehensive methods, e.g., calculation of the dust storm index, have been developed for characterizing the dust climatology $[8,14]$ to better use the information on dust strength defined in the weather codes. The index is based on different weights and contributions from these dust weather codes, as shown in the following equation [8]:

$\mathrm{DSI}=\sum_{i=1}^{n}[(5 \times \mathrm{SDS})+\mathrm{MDS}+(0.05 \times \mathrm{LDE})]_{i}$

The weight is defined according to the strength of dust weather, where DSI $=$ Dust Storm Index at $n$ stations, and $i$ is the $i$ th value of $n$ stations for $i$ from 1 to $n$. The number of stations $(n)$ is the total number of stations recording a dust event observation in the time period. The time is normally a year but can be a month or any sub-period of a year. SDS denotes severe dust storm days (daily maximum dust codes: 33-35), MDS is moderate dust storm days (daily maximum dust codes: 30-32 and 98), and LDE represents local dust event days (daily maximum dust codes: 07-09).

In using weather codes and their associated methods, the quality of records is an important issue. Since the code is recorded by individual observers, personal judgments and/or mistakes may seriously affect the data quality. Large uncertainties from human subjective judgments, the observational location, and environmental factors (e.g., brightness of sky) affect subsequently the data quality. The advantage of weather code data is their consistence. Although an absence of recording person may result in inconsistent data, the consistence of weather recording on the climate scale is very good compared with other data records.

Visibility can also be used as a dust weather indicator, and so it is recorded in regular weather observations metrically. Over dust storm source regions, the main air contaminant affecting air quality is dust, and so visibility is a good indicator for airborne dust concentrations. Several methods have been developed to identify dust weather based on this approach. A popular one is based on the Air Force Manual (AFMAN) surface weather observations [15], which define levels of dust storm as in Table 2.

Similar to the method of using dust weather codes, the dust storm climatology based on visibility can be reconstructed by determining whether the dust storm or severe dust storm occurred during a day. This method has been used in a series of dust climatology applications [16], but the potential problems in using visibility data may be similar to those in using weather code data. The standard approaches in measuring visibility have been updated several times as prescribed in the WMO's data manual. The early approach heavily depended on the observer's personal judgments, and the current approach is still subject to the observer's individual decisions. In addition, other environmental factors including cloud, precipitation, and downward solar radiation can also affect visibility. The 
Table 1 Weather observational codes for dust conditions

\begin{tabular}{ll}
\hline Dust weather codes & Description \\
\hline 06 & Widespread dust in suspension in the air \\
07 & Dust or sand raised by wind at or near the station at the time of observation \\
08 & Well-developed dust whirls or sand whirls seen or near the station \\
09 & Dust storm or sand storm within sight at the time of observation \\
30 & Slight or moderate dust storm or sand storm has decreased \\
31 & Slight or moderate dust storm or sand storm shows no appreciable change \\
32 & Slight or moderate dust storm or sand storm has begun or increased \\
33 & Severe dust storm or sand storm decreased \\
34 & Severe dust storm or sand storm shows no appreciable change \\
35 & Severe dust storm or sand storm has begun or increased \\
98 & Thunderstorm with dust or sand storm at time of observation \\
\hline
\end{tabular}

criteria in determining the dust storms may vary with locality, which is not considered in current methods. Therefore, using visibility data in identifying dust storms may contain significant uncertainty.

\section{In Situ Measurements of Air Quality}

In situ measurements of air quality are also used in analysis and identification of dust storm processes. Regular air quality observations on sites include two types, the aerosol optical depth (AOD) and concentration measurements and the atmospheric composition measurements. Both types can be used for dust storm studies. Similar to weather stations, air quality observations are limited by location. However, the spatial coverage of air quality networks is not as good and comprehensive as for meteorological observations. Thus, coverage and uniformity, especially over non-urban regions, are mainly problematic for analysis and applications of in situ air quality data. Table 3 summarizes the major stationary air quality observational networks or datasets that can be used for dust storm identification or climatology studies.

The AERONET (AErosol RObotic NETwork) program is a federation of ground-based remote sensing aerosol networks [17]. The EPA AQS (Air Quality System) is the repository of ambient air quality data maintained by US Environmental Protection Agency (EPA). The IMPROVE stands for Interagency Monitoring of Protected Visual Environments, a program resulted from the USA Clean Air Act and aimed to prevent future and remedy existing visibility impairment in the National Parks and wilderness areas. The Clean Air Status and Trends

Table 2 Dust storm definition using visibility observations

\begin{tabular}{ll}
\hline Strengths of dust storm weather & Visibility range \\
\hline Severe & Less than $500 \mathrm{~m}$ \\
Regular & More than $500 \mathrm{~m}$ and less than $1 \mathrm{~km}$ \\
Suspension & More than $1 \mathrm{~km}$ and less than $5 \mathrm{~km}$ \\
\hline
\end{tabular}

Network (CASTNET) is a national air quality monitoring network designed to provide data to assess trends in air quality, atmospheric deposition, and ecological effects due to changes in air pollutant emissions. The European Environmental Agency (EEA) Airbase is the public air quality database system of the EEA. The GALION is GAW (Global Atmosphere Watch, WMO) Aerosol Lidar Observations Network, and a network of networks, which makes use of existing systems at established stations, of the experienced operators of these systems, and of existing network structures. The major contributors to the GALION are EARLINET (European Aersol Research Lidar Network) in Europe, NDACC (Network for the Detection of Atmospheric Composition Change), ADNET (Asian Dust Network) in Asia, and MPLNET (Micro Pulse Lidar Network).

The implementation of surface AOD is used in desert regions where dust particles are the dominant contributor to atmospheric aerosols. Many regional and global AOD networks are available for dust storm identifications. As one of the most broadly distributed networks, AERONET has been used in dust storm studies over many areas of the world [18-20]. Alam et al. [21] studied the dust storms over the Middle East and their impacts on total aerosols, whereas Prasad and Singh [22] studied the dust storm climatology over northern India by using the AERONET sites over these regions. Since AOD observations can only be made during the day, records of nighttime dust storm processes are unavailable.

Relatively, stationary atmospheric composition measurements are not affected by diurnal cycles. Dust particles are major components of captured atmospheric aerosol samples. In desert regions, the mass ratio of dust particles in total aerosols can be above $35 \%$ in non-dust storm days [23]. However, it must be pointed out when attempting to obtain dust measurements in areas that are in, adjacent, or downwind of cities, there are diurnal cycles of vehicle traffic and transportation which need to be subtracted to get the dust data [24].

Observed total aerosol samples can also provide mass concentrations estimated for dust through composition analyses. Methods using the dust mass concentrations have been 
Table 3 Summary of major in situ air quality datasets or networks

\begin{tabular}{lllll}
\hline Name & Coverage & Data type & Availability & Web address \\
\hline AERONET & Global & Aerosol optical & $2006 \sim$ Present & aeronet.gsfc.nasa.gov \\
EPA AQS & USA & Mass composition & $1993 \sim$ Present & www.epa.gov/ttn/airs/airsaqs \\
IMPROVE & USA & Mass/chemical composition & $1988 \sim$ Present & vista.cira.colostate.edu/improve \\
CASTNET & USA & Chemical composition & $1991 \sim$ Present & www.epa.gov/castnet \\
EEA airbase & Europe & Mass composition & $1997 \sim$ Present & acm.eionet.europa.eu/databases/airbase/index.html \\
GALION & Global & Aerosol optical & $\sim$ Present & wmo.int/pages/prog/arep/gaw/aerosol.html \\
\hline
\end{tabular}

developed for dust climatology reconstructions over regions with air quality observations [5, 7]. Several criteria have been suggested for dust storm identification based on dust aerosol mass concentrations. One of the major challenges for this method is that the bases of dust aerosol concentration are non-comparable in different surface environments. For instance, dust aerosol concentration classified as a dust storm over an urban region may be close to the level on a non-dust storm day over a desert region. This may result in the erroneous identification of dust storms by using these criteria [10••]. In addition to the instant concentration information that stationary atmospheric composition measurements can provide, the concentration variation trend can also be used for dust storm identification [10••]. For many locations, dust mass concentration changes during the dust storm process and is significantly above the normal concentration level. An approach based on the trend identification has been developed by Lei et al. $[10 \bullet \cdot]$ to avoid the defects in using dust concentrations alone. Based on the variation trend, dust storms can also be classified into several types.

\section{Satellite Observations of Dust Records}

As a recent developed high technology, satellites have been used in monitoring dust storms, resulting in a significant improvement in their mapping and examination. Specific satellite sensors and equipment have been developed to observe the detailed structure, processing, and impact of dust storm events. These sensors include microwaves, visible channels, and lidar. The observation is also not limited to snapshots for single/ individual dust storm events, since the satellites can cover a large area with a consistent temporal frequency. On the global scale, major dust source regions have been identified using satellite data, such as from the Total Ozone Mapping Spectrometer (TOMS; [25, 26]). The passage of dust storms and along their transport pathways over land and ocean have also been tracked using TOMS and Cloud-Aerosol Lidar and Infrared Pathfinder Satellite Observations (CALIPSO) [27]. A few satellites provide higher temporal and spatial resolutions for dust storm diagnostics and identification, and they are listed in Table 4.

Sensor-retrieved parameters (such as MODIS aerosol size parameters; [39-41]) or complex statistical analyses (such as
Principal Component Analysis; e.g., [40, 42, 43]) have also been used to differentiate dust and non-dust with some success.

Among various satellites, CALIPSO and MODIS observe the global AOD [44], which is suitable for providing consistent dust data over dust regions. With the Cloud-Aerosol Lidar with Orthogonal Polarization instrument on board, CALI PSO can provide a global profile that complements passive sensors when observing dust aerosols from space.

As introduced above, MODIS satellite data cover a global domain. For the bare ground surface of the Sahara desert, MODIS can provide a series of daily products in investigating the global aerosols including the AOD, deep blue AOD, dust mask, and visible images [45]. Since the dust aerosol dominates the total aerosols over desert regions, these aerosol optical products provide a very good reference to dust concentrations. Ma et al. [46•*] compare nearly 6 years of CALIPSO AOD data (June 2006 through 2011) with AOD from MODIS during the same period (Fig. 1). While the spatial distribution and seasonal variability of CALIPSO AOD is generally consistent with that of MODIS, CALIPSO is overall lower than MODIS as the latter has a higher frequency than the former for most bins of AOD. The correlation between MODIS and CALIPSO is better over ocean than over land. The study also found that CALIPSO AOD is significantly lower than MODIS AOD over dust regions during the whole time period, with a maximum difference of 0.3 over the Saharan region and 0.25 over Northwest China. Although this may indicate that the satellite-retrieved algorithm may need further adjustment, the result of AOD can be a good reference to dust storm studies [47].

Beside the products listed above, a few other satellite instruments may also provide aerosol optical information. These platforms include MISR (the Multi-angle Imaging SpectroRadiometer), OMI (Ozone Monitoring Instrument), and VIIRS (Visible Infrared Imaging Radiometer Suite).

\section{Common Data Sources for Major Desert Regions}

\section{Sahara Desert}

Northern Africa is the most seriously dust storm-affected region of the world, with dust storms in the Sahara Desert 
Table 4 List of high resolution satellite data sources

\begin{tabular}{lr} 
Data sources & References \\
\hline AVHRR (advanced very high resolution radiometer) polar orbit operational satellite & {$[28,29]$ and etc. } \\
VISSR (visible infrared spin-scan radiometer) geostationary operational environmental satellite & {$[30]$ and etc. } \\
MODIS (moderate resolution imaging spectroradiometer) sun-synchronous orbit satellite & {$[31-35]$ and etc. } \\
MSG SEVIRI (meteosat second generation-spinning enhanced visible and infrared imager) EUMETSAT & {$[36,37]$ and etc. } \\
SeaWIFS (sea-viewing wide field-of-view sensor) polar orbit environmental satellite & {$[38]$ and etc. }
\end{tabular}

mainly caused by the northeasterly trade winds over Nigeria and Guinea [50]. The major source areas include the Bodélé Depression [51, 52], an area comprising southern Mauritania, northern Mali, and central southern Algeria [53]; southern Morocco and western Algeria; the southern fringes of the Mediterranean sea in Libya [54] and Egypt [55]; and northern Sudan [56].

Data quality of meteorological observations is a major issue in many African countries. Studies using weather codes need careful quality control strategies, but there are not many studies on Saharan dust using weather code methods. However, Cowie et al. [57] recently analyzed the detailed dust emission from long-term (1984-2012) surface synoptic observations over the Saharan and Sahel regions. This study set a good reference to future studies on African dust storms using meteorological data and attempts to balance the quality of the dataset with spatial coverage by including imperfect station records and making their limitations clear. Initial criteria were used to eliminate
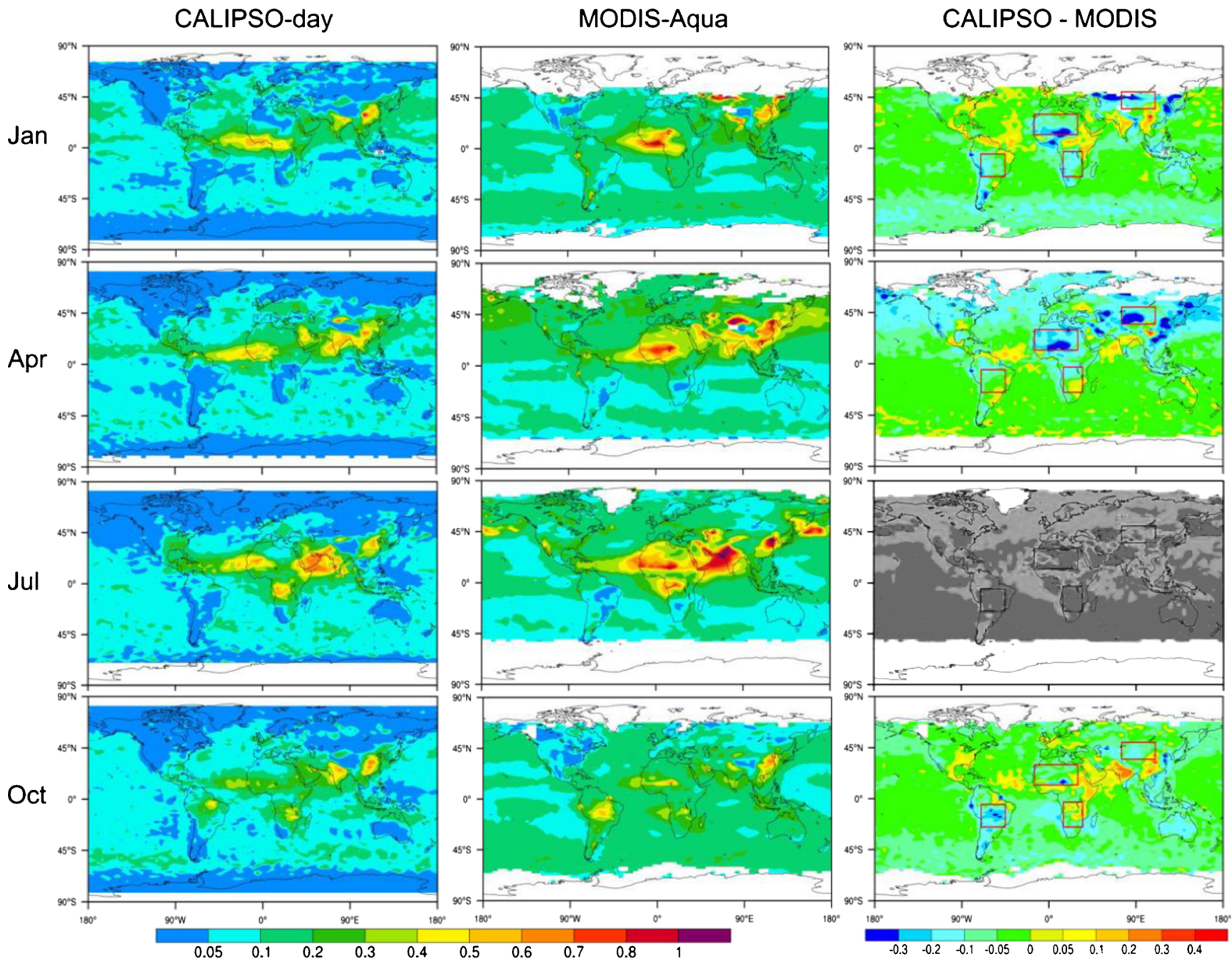

Fig. 1 Multi-year averaged (2006-2011) AOD from CALIPSO daytime, MODIS Aqua, and their differences in January, April, July, and October. The red rectangles shown in the right-column plots mark the regions of the Sahara, Northwest China, South Africa, and South America (Fig. 6 of [46••]) 
extremely biased and patchy stations or those that simply did not have enough dust reports to produce meaningful statistics, which left 70 stations to work with. Quality flags assigned to these stations gave indications as to the results that should be approached with caution, such as the diurnal cycle in the Sahel where a daytime bias is present. Frequency of dust emission is compiled from the weather codes of 7-9, 30-35, and 98. These statistics are further split into dust storm frequency (DSF) including only the codes of 9, 30-35, and 98 and blowing dust frequency represented by the codes of 7 and 8 . The result shows that spring is the dominant season for Saharan dust storm activities with dust events in cool seasons less frequent but more intense when they occur [57].

Due to the lack of consistent air quality monitoring networks over the African countries, a long-term dust storm climatology study based on particulate matter data is unavailable. However, air quality measurements in this region have been used to examine the Saharan dust events, especially in transport and impact studies [58-60]. Figure 2 shows the typical chemical compositions of dust storms observed in the Sahara desert or its closely impacted area. It is also found that the chemical composition of the transported Saharan dust was more homogeneous than the composition of individual soils [61]. As confirmed by the air mass back trajectories, the higher level of homogeneity of the aerosol is partly because a dust event affects a large area of the Sahara desert and the composition of the particles reflects its average composition [62].

Limited studies and data sources are available to draw a comprehensive dust composition map. However, a series of major components and their ratios have been provided in previous studies. Although these observations did not use a unified analysis standard, the characteristics and difference among sources can be identified. All figures of chemical characteristics in this section show only the reported ratios of components in samples. The unreported mass ratio for each region is summarized as others, which may include some regular compositions of the earth crustal, e.g., $\mathrm{H}_{2} \mathrm{O}, \mathrm{C}$, O, etc.

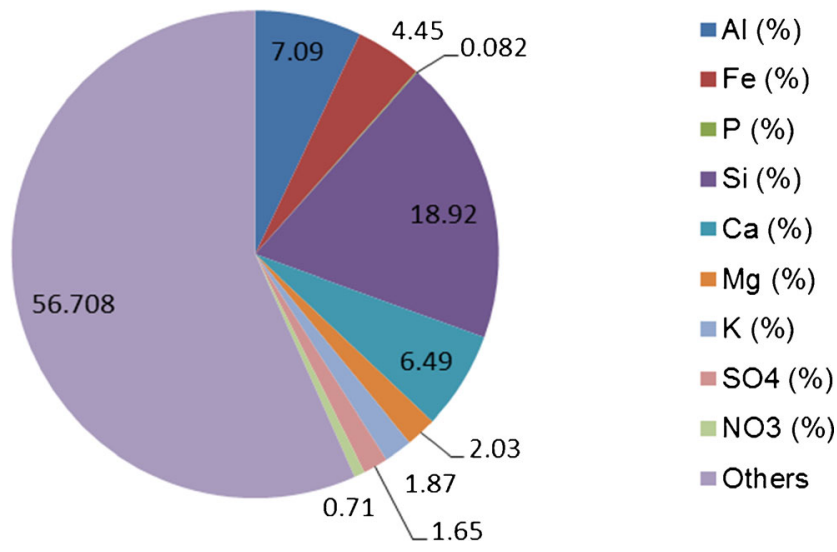

Fig. 2 Chemical characteristics of Saharan dust. Mean percentages of components measured in previous studies (Data source: [58, 59])

\section{Asian Deserts}

Middle and eastern Asia is also a significant dust storm source region, and studies of dust loading and fluxes indicate major source deserts including the Gobi [63, 64], Taklimakan [65], and Badan Jarain [66] deserts. Dust storms over this region have been well studied in the past decades due to their serious impacts on the social-economic centers of East Asian countries.

Dust weather codes in meteorological records have been widely used in dust storm studies in East Asia. However, the name and category of dust weather codes are defined differently, in comparison with those discussed in section 1.1, and these practices are still ongoing in places such as China. Observed surface weather phenomena is usually required in this method $[63,67]$ and describes the dust weather by four strength codes: dust-in-suspension, blowing dust, dust storms, and severe dust storms. Ding et al. [68] used the dust weather records from 338 stations over China to study long-term (1960-2003) dust climatology and its tele-connection with atmospheric circulations, while Lei et al. [67] and Sun et al. [63] used the weather codes to validate their dust storm prediction models. A long-term seasonal trend of Asian dust storm activities has been constrained from meteorological records [69]. Spring is shown as the most frequent season for dust storm disasters [70, 71].

The air quality monitoring network was established gradually in China during the last couple of decades, and therefore, the data are too limited to reveal long-term dust climatology. Independent observations and field campaigns over China can provide effective information about dust compositions in the country. Zhang et al. [72] studied the chemical compositions of spring dust storms in Beijing and their comparison to the deposition in non-dust storm days. Wang et al. [73] analyze the monthly samples obtained from April 2001 to March 2002 at 29 sites in sandy and Gobi deserts, steppes, and loess areas across North China. The results show the typical characteristics of chemical compositions of dust storms in East Asia (Fig. 3), revealing that Asian dust features high concentrations of $\mathrm{Si}, \mathrm{Al}, \mathrm{Fe}, \mathrm{Ca}$, and $\mathrm{K}$. Compared with Saharan dust, the relative ratio increase in $\mathrm{K}$ and $\mathrm{P}$ and decrease in $\mathrm{Ca}$ and $\mathrm{Mg}$ indicate that East Asian dust is more affected by farming sources.

\section{Middle Eastern Deserts}

Dust storms in the Middle East are mainly from the Arabian desert [74, 75], with Oman and parts of Saudi Arabia providing large generation areas in the east, and northern parts of Iraq and Iran are also major dust lofted areas [76]. Studies of dust activities and impacts of the Arabian Desert are usually combined with Saharan dust [60], since the surrounding regions are affected by both sources. Independent studies of dust storms were also made in Arabian desert regions and it showed different characteristics from the Sahara desert. 


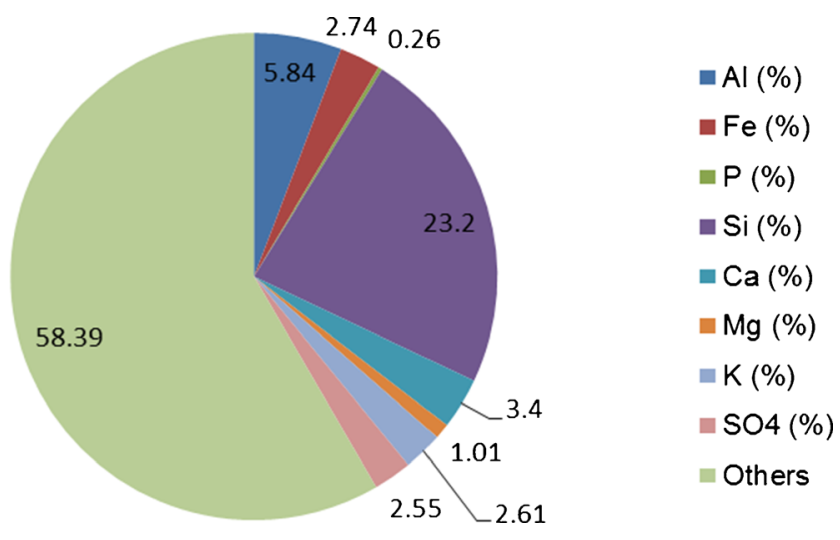

Fig. 3 Chemical characteristics of East Asian dust. Mean percentages of components measured in previous studies (Data source: [73, 74])

Previous studies of Middle East dust storms based on meteorological records usually used visibility as the parameter to identify dust storm events. Kutial and Furman [77] use the visibility data at 117 synoptic stations over the middlewestern region into a cluster analysis to group the typical dust storms. The identification of dust storms is based on the similarity in visibility reduction. A recent study by $\mathrm{Yu}$ et al. [78] further use the visibility records in this area to analyze dust storms, but adopts a simple identification criteria which defines dust storms as having visibility less than $1 \mathrm{~km}$. Notaro et al. [79] examined dust observations from 13 Saudi Arabian stations, revealing a mid-winter peak in DSF along the southern coast of the Red Sea, a spring peak across northern Saudi Arabia around the An Nafud desert, and an early summer peak in eastern Saudi Arabia around the Ad Dahna Desert.

Chemical compositions of the Arabian Desert have been investigated in a series of studies [80]. Aydin et al. [81] studied the chemical characteristics of Arabian and Saharan dust in the impact region of Anatolia, Turkey. Through analyzing the trace metal concentrations in dust day PM10 samples, the study shows that four metals (Fe, Al, Cr, Mn) are dominant in settled particles. Modaihsh [82] studied the dust sediments in Riyadh city, Saudi Arabia from March 1991 to February 1992, with the entire data set revealing that the dust fractions lie between loam and silt loam, having an average composition of $37 \%$ sand, $47 \%$ silt, and $16 \%$ clay. It is also shown that $\mathrm{CaCO} 3$ content, $\mathrm{EC}$, and $\mathrm{pH}$ value were rather high and averaged $31.8 \%, 4.8 \mathrm{dSm}-1$, and 8.9 , respectively. The data from both studies are combined and analyzed in Fig. 4 as the typical composition fraction of the Arabian Desert. Compared with other deserts, it is noted that the ratio of $\mathrm{Ca}$ is exceptionally high, which indicates that high granite component is a major feature in the Arabian Desert.

\section{North American Desert}

Northern American dust storms mainly occur over the western United States, including the Great Basin, Mojave, Sonora, and

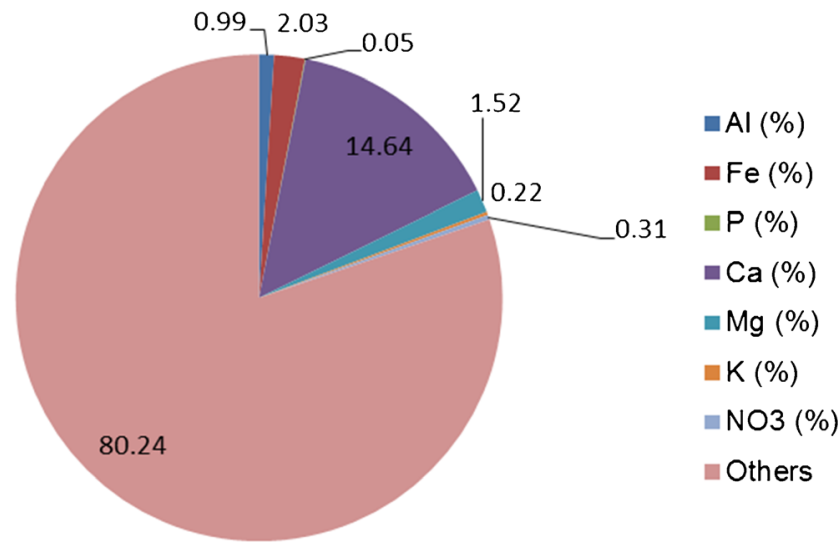

Fig. 4 Chemical characteristics of Arabian dust. Mean percentages of components measured in previous studies (Data source: [81, 82])

Chihuahua deserts and the Great Plain [5, 10••]. The dry climate drives dust storms all year round with peak strength and frequency in spring and summer [10••]. The decadal variability of North American dust is significant, with serious dust storm hazards during the 1930s creating one of the most severe environmental catastrophes in US history, which led to the popular characterization of much of the southern Great Plains as the "Dust Bowl." Recent dust activities have reduced and serious impacts usually occur in near-desert states including Arizona, Texas, and New Mexico.

The study of North American dust storms through meteorological records has been carried out in recent years. Through investigating the weather code, Hahnenberger and Nicoll [13] used regular meteorological records to study the meteorological characteristics of dust storm events in the eastern Great Basin of Utah. Similarly, Lei et al. [83] combined the weather code, air quality observations, and satellite AOD in investigating the long-term dust climatology in Phoenix, Arizona. Both studies show a skewed distribution with higher frequency of dust storm activities in July and August and relatively low activity during the remaining months.

Since the air quality monitoring network is relatively well developed in the United States, systematic observations of particulate matter have been used in previous dust storm analysis. Many approaches have been used in US dust storm identification. For instance, Kavouras et al. [84] developed a semiquantitative method to assess local dust contribution in the western USA by assuming that dust concentrations are equal to the sum of fine soil and coarse particles. Escudero et al. [85] used the increase in daily particulate matter concentration, with smaller than $10 \mu \mathrm{m}$ in diameter (PM10) over the regional background level, to quantify the daily dust load. Ganor, Stupp, and Alpert [86] developed and tested three criteria for determining a dust event: average PM10 level in half-hour exceeds $100 \mathrm{\mu gm}^{-3}$, the high level is maintained for no fewer than three hours, and peak PM10 is above $180 \mu^{-3} \mathrm{gm}^{-3}$. Furthermore, Tong et al. [5] use the aerosol observations derived from the Interagency Monitoring of Protected Visual 
Environments (IMPROVE) network to construct the DSF during 2000-2007 over the western United States based on a high PM10 level, a relatively low PM2.5 level [87], and the element distribution in the sample. The resulted dust climatology shows a similar summer peak as that from the meteorological record.

Figure 5 shows the composition characteristics of dust measurement in the Phoenix area of Arizona. The composition data was from the continuous aerosol measurements on an IMPROVE site in the rural area of Phoenix, which is a typical US southwestern city that is affected by dust storm weather all year around [83]. The IMPROVE monitoring sites that, with a few exceptions, are deployed in the national parks and wilderness areas of the United States [88], provide a good reference to natural dust storm events. The composition features high concentrations of $\mathrm{Fe}, \mathrm{Ca}$, and $\mathrm{SO}_{4}{ }^{2-}$ and low concentrations of $\mathrm{K}, \mathrm{Mg}$, and $\mathrm{P}$. The high concentrations are typical components of sand, while the low concentrations are typically composed of clay. This indicates that the dust source is likely to come from wind erosion of rocks rather than agricultural regions. However, it must note that the composition shown in the Fig. 5 over the Phoenix area may not be representative to dust storms peaked in Spring season over different locales in southwestern USA, such as in Texas.

\section{Australian Deserts}

Australia is a dry continent, with over $75 \%$ of its land surface classified as arid or semi-arid land. Dust storms are natural events that occur widely over Australia [89]. As a seriously affected region, Australian scientists began researching dust storms decades ago, and many case studies and modeling studies on Australian dust storms have been published (e.g., [90-93] and many others).

In Australia, the meteorological records have been used in dust storm studies for several decades [94, 95]. The approach was continuously improved, and advanced methods have

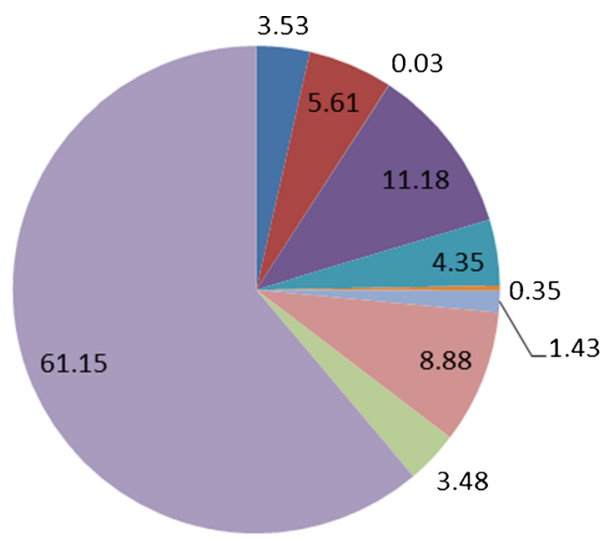

$$
\begin{aligned}
& \square \mathrm{Al}(\%) \\
& \square \mathrm{Fe}(\%) \\
& =\mathrm{P}(\%) \\
& \square \mathrm{Si}(\%) \\
& \square \mathrm{Ca}(\%) \\
& \square \mathrm{Mg}(\%) \\
& \square \mathrm{K}(\%) \\
& \square \mathrm{SO} 4(\%) \\
& \square \mathrm{NO} 3(\%) \\
& \square \text { Others }
\end{aligned}
$$

Fig. 5 Chemical characteristics of dust in Phoenix, Arizona, USA. Mean percentages of components measured by IMPROVE network in March 2003 been developed in using weather codes [8]. This progress has also benefited from good quality meteorological operations on dust weather recording. The Bureau of Meteorology has been a key component of national drought management since 1965. The dust weather codes are an integral portion of the nationwide daily observation network and help to assess the current situation and provide early indication of the need for contingency action. Therefore, Australian meteorology data are highly utilized in dust storm studies. As a latest progress on the weather code approach, O'Loingsigh et al. [8] update a Dust Storm Index (DSI) by using different weighting on the dust weather codes. This method considers the strength variations among different dust storm events or over different locations. The DSI can represent the temporal and spatial pattern of dust storm activities. Similar to most continental dust storm activities, Australian dust storms show a late spring peak (October-November for the late spring of the southern hemisphere).

Chemical characteristics of Australian dust storms have been studied by several field campaigns [96-98], although a consistent monitoring network specifically designed for dust aerosols is unavailable in the country. Through integrating data from these field campaigns, a composition diagram is presented in Fig. 6. This composition shows a different type of source, which may originate from both desert and agricultural areas.

\section{South American Deserts}

In South America, dust storms occur in the western parts of the continent covering areas of Bolivia, Chile, and Argentina. Prospero et al. [25] have shown that there are three persistent dust sources: Patagonia, central-western Argentina, and the Puna-Altiplano Plateau. To the west of Buenos Aires in Argentina, more than eight dust storms are reported per year [97]. Winter (June to August for the South Hemisphere) is a peak season for South American dust storms [25, 98].

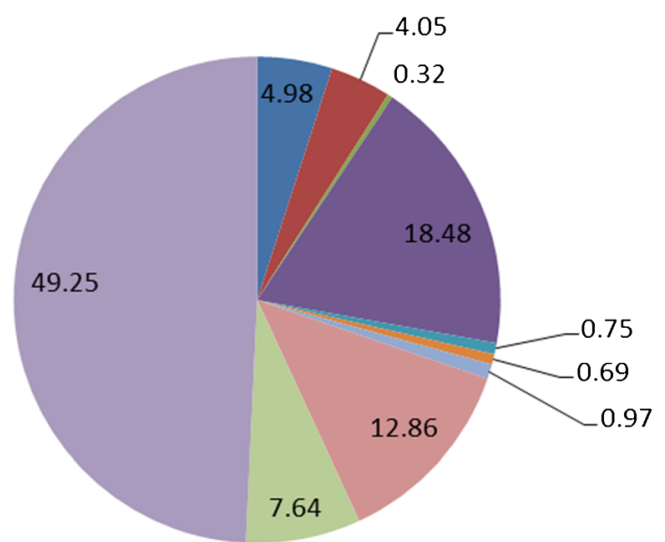

$$
\begin{aligned}
& =\mathrm{Al}(\%) \\
& =\mathrm{Fe}(\%) \\
& =\mathrm{P}(\%) \\
& =\mathrm{Si}(\%) \\
& =\mathrm{Ca}(\%) \\
& =\mathrm{Mg}(\%) \\
& \square \mathrm{K}(\%) \\
& =\mathrm{SO} 4(\%) \\
& \square \mathrm{NO} 3(\%) \\
& \square \text { Others }
\end{aligned}
$$

Fig. 6 Chemical characteristics of dust in Australia. Mean percentages of components measured during dust storm events (Data source: [48, 49]) 


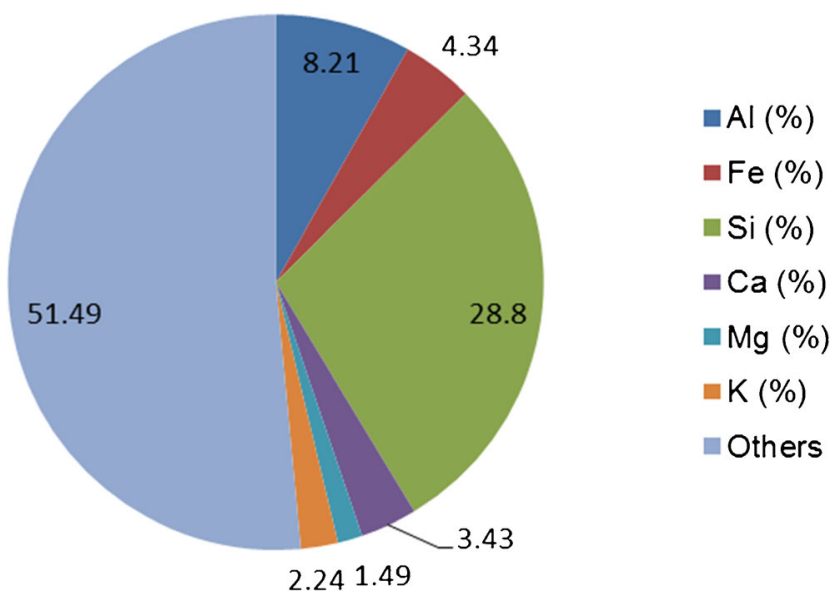

Fig. 7 Chemical characteristics of dust in Patagonia, South America. Mean percentages of components measured during dust storm events (Data source: [100])

The presence of extensive areas of closed depressions and of wind fluted topography, combined with the probable importance of salt weathering in the generation of fine material for deflation [99], suggest that the dry areas of the Puna and Altiplano should be major source areas for dust storms [98]. TOMS identifies one area where aerosol values are relatively high, the Salar de Uyuni, a large closed basin in Bolivia. It is probable that the deflation of fine sediments from its desiccated floor is one of the reasons for the existence of high aerosol values in this region. Gaiero et al. [100] studied the chemical composition of the dust storms in Patagonia, finding that the volcanism has important contributions to the dust storm source in Patagonia (Fig. 7).

\section{Discussion}

As extreme meteorological events, dust storms are major natural hazards. Research has been conducted into major dust affected regions, yet studies are far from comprehensive and the status of research is unbalanced for all regions. Such limitations are the result of a lack of quality observational data on dust storms, with a serious influence on long-term climatology studies and model verifications.
Since specifically designed observations with good coverage for dust activities are unavailable, other data sources have been analyzed in recent decades, with significant progress made in this aspect. Table 5 summarizes the characteristics of major dust-prone regions over the world.

Seasonal variability of dust frequency in each region largely depends on their local climate and surface conditions. Previous studies show that the peak dust frequency tends to occur in spring when the meteorology and soil conditions are suitable for wind erosion. As approaches used in recent studies, meteorological records, air quality measurements, and satellite AOD can provide a good coverage to constrain the historical dust storm images. Through the review, it is noted that not all dataset or dust series reconstruction approaches are used in each region. Due to the diversity in data quality and availability, the final choice of data for appropriate studies may differ in different regions.

However, existing datasets may not meet the requirements for dust storm studies. The modeling study of dust storms needs accurate observations of dust concentrations, which means not only accurate on instantaneous value but also the exact description of the location and temporal stage of the dust storm event. Current meteorological records do not provide dust concentration information, and air quality observations usually are obtained over a period of time. There is a lack of information on instantaneous flux and dust concentrations on different vertical layers. The temporal intervals of air quality sampling are too large to capture the peak value of a dust storm, and satellite AOD can provide the reference to total column integration on dust concentrations. It is necessary to identify the vertical structure in data retrieval. Satellite AOD is also seriously affected by cloud coverage, which may largely reduce the effectiveness of data for practical use. Another limitation of Satellite AOD is differentiating dust from volcanic ash, urban aerosols, etc. Further improvements in satellite technology and related data retrieval algorithm are needed to enhance these aspects.

Although the seasonality of dust storms over each dustprone region is well understood, an understanding of longterm dust storm climatology and climate feedback still needs much work. The inter-annual variability of dust storms over most dust-prone regions is not well understood, which may further affect the improvement of climate-scale numerical dust

Table 5 Characteristics of dust activities

\begin{tabular}{llll}
\hline Region & Peak season & Dust sources type & Common data source \\
\hline Sahara & Boreal spring & Desert & Weather code, AOD, satellite data \\
Asian & Boreal spring & Desert, farm & Weather code, satellite data \\
Middle East & Boreal spring-summer & Desert & Weather code, visibility, satellite data \\
North America & Boreal spring-summer & Desert & Weather code, visibility, AOD, satellite data \\
Australia & Austral spring (October-November) & Desert, farm & Weather code, satellite data \\
South America & Austral winter (June, July, August) & Desert, volcano & Satellite data \\
\hline
\end{tabular}


prediction systems. Further work on long-term dust storm climatology may need to improve the approaches in historical dust storm identification based on current datasets. For instance, the dust storm index method is an advancement on the weather code method. However, the method has not been used in other regional studies, which may need further modification to adapt to the diversity of data quality. Climate and dust interaction studies may also facilitate the improvement of physical dust models by providing effective clues.

Finally, it must be noted that there have been many field campaigns either designed for dust monitoring or carrying dust-monitoring equipment. These campaign data have played a pivotal role in dust storm research including modeling. This important data source is beyond the scope of the current review that focuses on climate studies related to long-term data availability and continuity.

Acknowledgments The author wishes to thank Dr. Hang Lei for his generous support on this project. The constructive comments and suggestions from two unanimous reviewers are greatly appreciated. The views expressed are those of author and do not necessarily reflect those of the sponsoring agencies. Any use of trade, product, or firm names is for descriptive purposes only and does not imply endorsement by the US Government

Conflict of Interest Julian X.L. Wang declares that he has no conflict of interest.

\section{References}

Papers of particular interest, published recently, have been highlighted as:

•• Of major importance

1. Goudie AS, Middleton NJ. Desert dust in the global system. Heidelberg: Springer Verlag; 2006.

2. Schubert SD, Suarez MJ, Pegion PJ, Koster RD, Bacmeister JT. On the cause of the 1930s dust bowl. Science, 200419 March 2004: 1855-1859.

3. Lin Z, Levy J, Lei H, Bell M. Advances in disaster modeling, simulation and visualization for sandstorm risk management in North China. Remote Sens. 2012;4:133754 .

4.• Goudie AS. Desert dust and human health disorders. Environ Int. 2014;63:101-13. It provides a comprehensive review of global distribution of dust sources from the perspective of its impact on human health.

5. Tong DQ, Dan M, Wang T, Lee P. Long-term dust climatology in the western United States reconstructed from routine aerosol ground monitoring. Atmos Chem Phys. 2012;12:5189-205.

6.• Chin M, Diehl T, Dubovik O, Eck TF, Holben BN, Sinyuk A, et al. Light absorption by pollution, dust, and biomass burning aerosols: a global model study and evaluation with AERONET measurements. Ann Geophys. 2009;27(9):3439-64. Through modeling against AERONET data, it provides a good illustration of model deficiencies on aerosol size distributions, the refractivity of dust and black carbon aerosols, and biomass burning emissions.
7. Bell ML, Dominici F, Ebisu K, Zeger SL, Samet JM. Spatial and temporal variation in PM2.5 chemical composition in the United States for health effects studies. Environ Health Perspect. 2007;115:989-95.

8. O'Loingsigh T, McTainsh GH, Tews E, Strong C, Leys J, Tapper NJ, et al. The Dust Storm Index (DSI): a method for monitoring broadscale wind erosion using meteorological records. Aeolian Res. 2014;12:29-40.

9.• Ginoux P, Prospero JM, Gill TE, Hsu NC, Zhao M. Global-scale attribution of anthropogenic and natural dust sources and their emission rates based on MODIS Deep Blue aerosol products. Rev Geophys. 2012;50:RG3005. doi:10.1029/2012RG000388. Based on the MODIS Deep Blue estimates, a global dust sources distribution is generated, and associated attributions are discriminated against natural and anthropogenic courses.

10.• Lei H, Wang JXL. Observed characteristics of dust storm events over the western United States using meteorological, satellite, and air quality measurements. Atmos Chem Phys. 2014;14:7847-57. doi:10.5194/acp-14-7847-2014. Based on satellite remote sensing and in-situ observations of meteorology and air quality, it characterizes dust storms under typical weather conditions, which provides a framework for improving understanding and mitigating effects of dust hazards.

11. National Climatic Data Center (NCDC) 2011. Global Integrated Surface Hourly (ISH) Database. http://www.ncdc.noaa.gov/oa/ land.html.

12. Dagsson-Waldhauserova P, Arnalds O, Olafsson H. Long-term frequency and characteristics of dust storm events in Northeast Iceland (1949-2011). Atmos Environ. 2013;77:117-27.

13. Hahnenberger M, Nicoll $\mathrm{K}$. Meteorological characteristics of dust storm events in the eastern Great Basin of Utah, U.S.A. Atmos Environ. 2012;60:601-12. doi:10.1016/j.atmosenv.2012.06.029. ISSN 1352-2310.

14. O'Loingsigh T, McTainsh GH, Tapper NJ, Shinkfield P. Lost in code: a critical analysis of using meteorological data for wind erosion monitoring. Aeolian Res. 2010;2:49-57.

15. Air Force Manual (AFMAN) 15-111. Surface weather observations, September 2001.

16. Yu Y, Notaro M, Liu Z, Kalashnikova O, Alkolibi F, Fadda E, et al. Assessing temporal and spatial variations in atmospheric dust over Saudi Arabia through satellite, radiometric, and station data. J Geophys Res Atmos. 2013;118:13,253-64. doi:10.1002/ 2013JD020677.

17. Holben BN, Eck TF, Slutsker I, Tanre D, Buis JP, Setzer A, et al. AERONET - a federated instrument network and data archive for aerosol characterization. Rem Sens Environ. 1998;66:1-16.

18. Kim D, Chin M, Yu H, Eck TF, Sinyuk A, Smirnov A, et al. Dust optical properties over North Africa and Arabian Peninsula derived from the AERONET dataset. Atmos Chem Phys. 2011;11(20):10733-41.

19. Lee J, Kim J, Yang P, Hsu NC. Improvement of aerosol optical depth retrieval from MODIS spectral reflectance over the global ocean using new aerosol models archived from AERONET inversion data and tri-axial ellipsoidal dust database. Atmos Chem Phys. 2012;12(15):7087-102.

20. Torres O, Bhartia PK, Herman JR, Sinyuk A, Ginoux P, Holben B. A long-term record of aerosol optical depth from TOMS observations and comparison to AERONET measurements. J Atmos Sci. 2002;59:398-413.

21. Alam K, Trautmann T, Blaschke T, Subhan F. Changes in aerosol optical properties due to dust storms in the Middle East and Southwest Asia. Remote Sens Environ. 2014;143:216-27. doi: 10.1016/j.rse.2013.12.021.

22. Prasad AK, Singh RP. Changes in aerosol parameters during major dust storm events (2001-2005) over the Indo-Gangetic Plains 
using AERONET and MODIS data. J Geophys Res-Atmos. 2007;112(D9).

23. Harrison RM, Jones AM, Lawrence RG. Major component composition of PM10 and PM2.5 from roadside and urban background sites. Atmos Environ. 2004;38:4531-8.

24. Achilleos S, Evans JS, Yiallouros PK, Kleanthous S, Schwartz J, Koutrakis P. PM10 concentration levels at an urban and background site in Cyprus: the impact of urban sources and dust storms. J Air Waste Manage Assoc. 2014;64(12):1352-60.

25. Prospero JM, Ginoux P, Torres O, Nicholson SE, Gill TE. Environmental characterisation of global sources of atmospheric soil dust identified with the Nimbus 7 Total Ozone Mapping Spectrometer (TOMS) absorbing aerosol product. Rev Geophys. 2002;40:2-31.

26. Washington R, Todd M, Middleton N, Goudie AS. Global dust storm source areas determined by the total ozone monitoring spectrometer and ground observations. Ann Assoc Am Geogr. 2003;93:297-313.

27. Alpert P, Kishcha P, Shtivelman A, Krichak SO, Joseph JH. Vertical distribution of Saharan dust based on 2.5-year model predictions. Atmos Res. 2004;70:109-30.

28. Evan AT, Heidinger AK, Pavolonis MJ. Development of a new over-water advanced very high resolution radiometer dust detection algorithm. Int J Remote Sens. 2006;27:3903-24. doi:10.1080/ 01431160600646359.

29. Zhu A, Ramanathan V, Li F, Kim D. Dust plumes over the Pacific, Indian, and Atlantic oceans: climatology and radiative impact. J Geophys Res-Atmos, 2007; 112.

30. MacKinnon PS, Chavez Jr RS, Fraser TC, Niemeyer DA, Gillette. Calibration of GOES-VISSR, visible-band satellite data and its application to the analysis of a dust storm at Owens Lake, California. Geomorphology. 1996;17:229-48. 1-3 SPEC. ISS

31. Badarinath KVS, Kumar Kharol S, Kaskaoutis DG, Kambezidis HD. Dust storm over Indian region and its impact on the ground reaching solar radiation - a case study using multi-satellite data and ground measurements. Sci Total Environ. 2007;384:316-32.

32. Gassó S, Stein AF. Does dust from Patagonia reach the subAntarctic Atlantic Ocean. Geophys Res Lett. 2007;34:L01801. doi:10.1029/2006GL027693.

33. Kaskaoutis DG, Kambezidis HD, Nastos PT, Kosmopoulos PG. Study on an intense dust storm over Greece. Atmos Environ. 2008;42(9):6884-96.

34. McGowan HA, Clark A. A vertical profile of PM10 dust concentrations measured during a regional dust event identified by MODIS Terra, western Queensland, Australia. J Geophys Res. 2008;113:F02S03. doi:10.1029/2007JF000765.

35. Zha Y, Li L. Influence of the 17 April 2006 dust storm on moderate resolution imaging spectroradiometer data for land cover identification. J Geophys Res. 2007;112:D14205. doi:10.1029/ 2006JD007869.

36. Moorthy KK, Babu SS, Satheesh SK, Srinivasan J, Dutt CBS. Dust absorption over the "Great Indian Desert" inferred using ground-based and satellite remote sensing. J Geophys Res. 2007;112:D09206. doi:10.1029/2006JD007690.

37. Schepanski K, Tegen I, Laurent B, Heinold B, Macke A. A new Saharan dust source activation frequency map derived from MSG SEVIRI IR-channels. Geophys Res Lett. 2007;34:L18803. doi:10. 1029/2007GL030168.

38. Eckardt FD, Kuring N. SeaWIFS identified dust sources in the Namib Desert. Int J Remote Sens. 2005;26(19):415967.

39. Dubovik O, Lapyonok T, Kaufman YJ, Chin M, Ginoux P, Kahn RA, et al. Retrieving global aerosol sources from satellites using inverse modeling. Atmos Chem Phys. 2008;8(2):209-50.
40. Jones TA, Christopher SA. Multispectral analysis of aerosols over oceans using principal components. IEEE Trans Geosci Remote Sens. 2008;46(9):2659-65.

41. Kaufman YJ, Koren I, Remer LA, Tanré D, Ginoux P, Fan S. Dust transport and deposition observed from the Terra-moderate resolution imaging spectroradiometer (MODIS) spacecraft over the Atlantic Ocean. J Geophys Res. 2005;110:D10S12. doi:10.1029/ 2003JD004436.

42. Agarwal VK, Mathur A, Sharma R, Agarwal N, Parekh. A study of air-sea interaction following the tsunami of 26 December 2004 in the eastern Indian Ocean. Int J Rem Sens. 2007;28(13-14): 3113-9.

43. Zubko V, Kaufman YJ, Burg RI, Martins JV. Principal components analysis of remote sensing of aerosols over oceans. IEEE Trans Geosci Remote Sens. 2007;45(3):730-45.

44. Kahn RA, Nelson DL, Garay MJ, Levy RC, Bull MA, Diner DJ, et al. MISR aerosol product attributes and statistical comparisons with MODIS, transactions on geoscience and remote sensing, IEEE T. Geosci Rem. 2009;47(12):4095-114. doi:10.1109/ TGRS.2009.2023115.

45. Remer LA, Kaufman YJ, Tanr'e D, Matoo S, Chu DA, Martins $\mathrm{JV}$, et al. The MODIS aerosol algorithm, products, and validation. J Atmos Sci. 2005;62(4):947-73. doi:10.1175/JAS3385.1.

46.• Ma X, Bartlett K, Harmon K, Yu F. Comparison of AOD between CALIPSO and MODIS: significant differences over major dust and biomass burning regions. Atmos Meas Tech. 2013;6:2391401. doi:10.5194/amt-6-2391-2013. It systematically examined differences between CALIPSO and MODIS products on retrieval capability of various aerosol types, and provides remedy for improving satellite algorithm and data quality.

47. Peyridieu S, Chédin A, Tanré D, Capelle V, Pierangelo C, Lamquin N, et al. Saharan dust infrared optical depth and altitude retrieved from AIRS: a focus over North Atlantic - comparison to MODIS and CALIPSO. Atmos Chem Phys. 2010;10:1953-67. doi:10.5194/acp-10-1953-2010.

48. Radhi, Box MA, Box GP, Mitchell RM, Cohen DD, Stelcer E, et al. Size-resolved mass and chemical properties of dust aerosols from Australia's Lake Eyre Basin. Atmos Environ. 2010;44(29):3519 28. doi:10.1016/j.atmosenv.2010.06.016. ISSN 1352-2310.

49. Reynolds RL, Cattle SR, Moskowitz BM, Goldstein HL, Yauk K, Flagg $\mathrm{CB}$, et al. Iron oxide minerals in dust of the red dawn event in eastern Australia, September 2009. Aeolian Res. 2014;15:1-13. doi:10.1016/j.aeolia.2014.02.003. ISSN 1875-9637.

50. Breuning-Madsen H, Awadzi TW. Harmattan dust deposition and particle size in Ghana. Catena. 2005;63:23-38.

51. Goudie AS, Middleton NJ. Saharan dust storms: nature and consequences. Earth Sci Rev. 2001;56:179-204.

52. Bristow CS, Drake N, Armitage S. Deflation in the dustiest place on Earth: the Bodélé depression Chad. Geophys J Roy Astron Soc. 2009; 105:50-8.

53. Knippertz P, Todd MC. The central west Saharan dust hot spot and its relation to African easterly waves and extratropical disturbances. J Geophys Res. 2010;115:D12117. doi:10.1029/ 2009JD012819.

54. O'Hara SL, Clarke ML, Elatrash MS. Field measurements of desert dust deposition in Libya. Atmos Environ. 2006;40:3881-97.

55. Koren I, Joseph JH, Israelevich P. Detection of dust plumes and their sources in northeastern Libya. Can J Remote Sens. 2003;29:792-6.

56. Brooks N, Chiapello I, Di Lernia S, Drake N, Legrand M, Moulin $\mathrm{C}$, et al. The climate-environment-society nexus in the Sahara from prehistoric times to the present day. J N Afr Stud. 2005;10:253-92.

57. Cowie SM, Knippertz P, Marsham JH. A climatology of dust emission events from northern Africa using long-term surface observations. Atmos Chem Phys. 2014;14:8579-97. doi:10.5194/ acp-14-8579-2014. 
58. Guieu C, Loÿe-Pilot M-D, Ridame C, Thomas C. Chemical characterization of the Saharan dust end-member: some biogeochemical implications for the western Mediterranean Sea. J Geophys Res. 2002;107(D15). doi: 10.1029/2001JD000582.

59. Formenti P, Elbert W, Maenhaut W, Haywood J, Andreae MO. Chemical composition of mineral dust aerosol during the Saharan Dust Experiment (SHADE) airborne campaign in the Cape Verde region, September 2000. J Geophys Res. 2003;108:8576. doi:10. 1029/2002JD002648. D18.

60. Palchan D, Stein M, Almogi-Labin A, Erel, Goldstein SL. Dust transport and synoptic conditions over the Sahara-Arabia deserts during the MIS6/5 and 2/1 transitions from grain-size, chemical and isotopic properties of Red Sea cores. Earth Planet Sci Lett. 2013;382(15):125-39. doi:10.1016/j.epsl.2013.09.013. ISSN 0012-821X.

61. Prospero JM. Long-term measurements of the transport of African mineral dust to the southeastern United States: implications for regional air quality. J Geophys Res. 1999;104:15917-27.

62. Lawrence $C$, Neff J. The contemporary physical and chemical flux of Aeolian dust: a synthesis of direct measurements of dust deposition. Chem Geol. 2009;267(1-2):46-63.

63. Sun J, Linna Z. Numerical simulation of two East Asian dust storms in Spring 2006. Earth Surf Process Landforms. 2008;33: 1892-911.

64. Dement'eva AL, Zhamsueva GS, Zayakhanov AS, Tsydypov VV, Ayurzhanaev AA, Azzayaa D, et al. Mass concentration of PM10 and PM2.5 fine-dispersed aerosol fractions in the eastern Gobi Desert. Russ Meteorol Hydrol. 2013;38:80-7.

65. Gao H, Washington R. The spatial and temporal characteristics of TOMS AI over the Tarim Basin, China. Atmos Environ. 2009;43: 1106-15.

66. Shao Y, Wang JJ. A climatology of Northeast Asian dust events. Meteorol Z. 2003;12:175-83.

67. Lei H, Lin Z, Sun J. An improved dust storm prediction system and its simulation experiments. Clim Environ Res. 2005;10:669-83.

68. Ding R, Li J, Wang S, Ren F. Decadal change of the spring dust storm in northwest China and the associated atmospheric circulation. Geophys Res Lett. 2005;32:L02808. doi:10.1029/ 2004GL021561.

69. Zhou ZJ, Wang XW. Analysis of the severe group dust storms in eastern part of northwest China. J Geogr Sci. 2002;12:357-62.

70. Liu Q, Liu Y, Yin J, Zhang M, Zhang T. Chemical characteristics and source apportionment of PM10 during Asian dust storm and non-dust storm days in Beijing. Atmos Environ. 2014;91:85-94.

71. Waggoner DG, Sokolik IN. Seasonal dynamics and regional features of MODIS-derived land surface characteristics in dust source regions of East Asia. Remote Sens Environ. 2010;114(10):212636.

72. Zhang R, Han Z, Cheng T, Tao J. Chemical properties and origin of dust aerosols in Beijing during springtime. Particuology. 2009;7(1): 61-7. doi:10.1016/j.partic.2008.11.003. ISSN 1674-2001.

73. Wang X, Dong Z, Zhang C, Qian G, Luo W. Characterization of the composition of dust fallout and identification of dust sources in arid and semiarid North China. Geomorphology. 2009;112(1-2): 144-57.

74. Middleton NJ, Goudie AS. Saharan dust: sources and trajectories. Trans Inst Brit Geogr. 2001;NS 26:165-81.

75. Givehchi R, Arhami M, Tajrishy M. Contribution of the Middle Eastern dust source areas to PM10 levels in urban receptors: case study of Tehran, Iran. Atmos Environ. 2013;75:287-95.

76. De Villiers M, van Heerden J. Nashi dust storm over the United Arab Emirates. Weather. 2011;66:79-81.

77. Kutial H, Furman HK. Dust storms in the Middle East: sources of origin and their temporal characteristics. Indoor Built Environ. $2003 ; 12: 419-26$.
78. Yu Y, Notaro M, Liu Z, Kalashnikova O, Alkolibi F, Fadda E, Bakhrjy F, Wang F. Climatic controls on the interannual to decadal variability in Saudi Arabian dust activity: towards the development of a seasonal dust prediction model, Submitted to JGR. 2014.

79. Notaro M, Alkolibi F, Fadda E, Bakhrjy F. Trajectory analysis of Saudi Arabia dust storms. J Geophys Res Atmos. 2013;118(12): 6028-43.

80. Flaounas E, Coll I, Armengaud A, Schmechtig C. The representation of dust transport and missing urban sources as major issues for the simulation of PM episodes in a Mediterranean area. Atmos Chem Phys. 2009;9:8091-101. doi:10.5194/acp9-8091-2009.

81. Aydin F, Aydin I, Erdogan S, Akba O, Isik B, Hamamci C. Chemical characteristics of settled particles during a dust-storm. Pol J Environ Stud. 2012;21(3):533.

82. Modaihsh AS. Characteristics and composition of the falling dust sediments on Riyadh city, Saudi Arabia. J Arid Environ. 1997;36(2):211-23.

83. Lei H, Wang JXL, Tong D, Lee P. Merged dust climatology in Phoenix, Arizona based on satellite and station data, submitted to Climate Dynamics. 2015.

84. Kavouras IG, Etyemezian V, Xu J, DuBois DW, Green M, Pitchford M. Assessment of the local windblown component of dust in the western United States. J Geophys Res. 2007;112: D08211. doi:10.1029/2006JD007832.

85. Escudero M, Querol X, Pey J, Alastuey A, Perez N, Ferreira F, et al. A methodology for the quantification of the net African dust load in air quality monitoring networks. Atmos Environ. 2007;41:5516-24.

86. Ganor E, Stupp A, Alpert P. A method to determine the effect of mineral dust aerosols on air quality. Atmos Environ. 2009;43:5463-8.

87. Reid JS, Koppmann R, Eck TF, Eleuterio DP. A review of biomass burning emissions part II: intensive physical properties of biomass burning particles. Atmos Chem Phys. 2005;5:799-825. doi:10. 5194/acp-5-799-2005.

88. Pitchford ML, Malm WC. Development and applications of a standard visual index. Atmos Environ. 1994;28:1049-54.

89. McTainsh GH, Leys J, Baker M, Tews K, Barton K. Wind erosion histories, model input data and community DustWatch. Brisbane: Griffith University; 2010.

90. McTainsh GH. Quaternary aeolian dust processes and sediments in the Australian region. Quat Sci Rev. 1989;8:235-53.

91. Shao Y, Leys JF, McTainsh GH, Tews K. Numerical simulation of the October 2002 dust event in Australia. J Geophys Res. 2007;112:D08207. doi:10.1029/2006JD007767.

92. Marx SK, Kamber BS, McGowan HA. Estimates of Australian dust flux into New Zealand: quantifying the eastern Australian dust plume pathway using trace element calibrated $210 \mathrm{~Pb}$ as a monitor. Earth Planet Sci Lett. 2005;239:336-51.

93. Cowie G, Lawson W, Kim N. Australian dust causing respiratory disease admissions in some North Island, New Zealand hospitals. N Z Med J. 2010;123:87.

94. Middleton NJ. Dust storms in Australia: frequency, distribution and seasonality. Search. 1984;15(1-2):46-7.

95. McTainsh GH, Pitblado JR. Dust storms and related phenomena measured from meteorological records in Australia. Earth Surf Process Landf. 1987;12:415-24.

96. Karlson LR, Greene RSB, Scott KM, Stelcer E, O'Loingsigh T. Characteristics of Aeolian dust across northwest Australia. Aeolian Res. 2014;12:41-6. ISSN 1875-9637.

97. Middleton NJ. The geography of dust storms. Unpublished DPhil Thesis. University of Oxford, 1986.

98. Gaiero DM, Simonella L, Gasso S, Gili S, Stein AF, Soas P, et al. Ground/satellite observations and modeling of dust storms originating in the high Puna-Altiplano desert (South America): 
implications for the interpretation of paleo-climatic archives. $\mathrm{J}$ Geophys Res Atmos. 2013;118:3817-31.

99. Goudie AS, Wells GL. The nature, distribution and formation of pans in arid zones. Earth Sci Rev. 1995;38:1-69.
100. Gaiero DM, Brunetb F, Probstb J-L, Depetrisa PJ. A uniform isotopic and chemical signature of dust exported from Patagonia: rock sources and occurrence in southern environments. Chem Geol. 2007;238:107-20. 